\title{
Senyawa Hidrazone dari Vanilin-DNPH Sebagai Sensor Kolorimetri Anion Sianida
}

\author{
S Suharman ${ }^{a *}$, Siti Utari Rahayu ${ }^{b}$ \\ ${ }^{a}$ Departemen Kimia, FMIPA, Universitas Sumatera Utara, Jl. T. Dr. Mansyur No. 9, Kel. Padang Bulan, \\ Kec. Medan Baru Sumatera Utara 201555 Telp. (0271) 663375 \\ ${ }^{b}$ Departemen Fisika, FMIPA, Universitas Sumatera Utara, Jl. T. Dr. Mansyur No. 9, Kel. Padang Bulan, \\ Kec. Medan Baru Sumatera Utara 201555 Telp. (0271) 663375 \\ * Corresponding Author \\ E-mail: suharman@usu.ac.id
}

DOI: 10.20961/alchemy.16.1.34635.77-93

Received 20 September 2020, Accepted 19 February 2020, Published 1 March 2020

\begin{abstract}
ABSTRAK
Senyawa hidrazon (E)-4-((2-(2,4-dinitrophenyl)hydrazineylidene)methyl)-2-methoxyphenol telah disintesis dari vanilin dan 2,4-dinitrofenilhidrazin (DNPH). Uji sensor anion dilakukan dengan menambahkan anion $\mathrm{F}^{-}, \mathrm{Cl}^{-}, \mathrm{Br}^{-}, \mathrm{I}^{-}, \mathrm{CN}^{-}, \mathrm{SO}_{4}{ }^{2-}, \mathrm{CO}_{3}{ }^{2-}, \mathrm{CH}_{3} \mathrm{COO}^{-}$dan $\mathrm{H}_{2} \mathrm{PO}_{4}^{-}$dalam pelarut asetonitril. Uji limit deteksi reseptor (E)-4-((2-(2,4-dinitrophenyl)hydrazineylidene)methyl)-2-methoxyphenol terhadap anion sianida dilakukan dalam pelarut asetonitril. Hasil uji sensor anion menunjukan bahwa reseptor selektif terhadap anion sianida dengan menghasilkan perubahan warna dari kuning ke merah. Hasil analisa dengan spektrofotometer UV-Vis reseptor memberikan perubahan panjang gelombang dari $395 \mathrm{~nm}$ menjadi $472 \mathrm{~nm}$ pada penambahan anion sianida. Reseptor (E)-4-((2-(2,4-dinitrophenyl)hydrazineylidene)methyl)-2methoxyphenol dapat mendeteksi anion $\mathrm{CN}$ - dengan limit deteksi sebesar $7 \mathrm{mM}$.
\end{abstract}

Kata kunci: hidrazon, kemosensor, kolorimetri, sianida, vanilin

\begin{abstract}
A Hydrazone Compound from Vanillin-DNPH as Colorimetric Sensor of Cyanide Anion. A hydrazone compound (E)-4-((2-(2,4-dinitrophenyl)hydrazineylidene)methyl)-2-methoxyphenol has been synthesized from vanillin and 2,4-dinitrophenylhydrazine (DNPH). The anion sensor study were done by adding $\mathrm{Br}^{-}, \mathrm{CN}^{-}, \mathrm{F}^{-}, \mathrm{SO}_{4}{ }^{2-}, \mathrm{Cl}^{-}, \mathrm{I}^{-}, \mathrm{CO}_{3}{ }^{2-}, \mathrm{CH}_{3} \mathrm{COO}^{-}$and $\mathrm{H}_{2} \mathrm{PO}_{4}^{-}$anion in acetonitrile solvent. The detection limit study of receptor $E)$-4-((2-(2,4-dinitrophenyl)hydrazineylidene)methyl)-2-methoxyphenol for cyanide anion was carried out in acetonitrile. The result of anion sensor study shows that the receptor was selective to cyanide anion by providing change of color from yellow to red. The analysis result using spectrophotometer ultraviolet-visible of the receptor provided change of maximum wavelength from $395 \mathrm{~nm}$ to $472 \mathrm{~nm}$ when the cyanide anion was added. Receptor (E)-4-((2-(2,4-dinitrophenyl) hydrazineylidene)methyl)-2-methoxyphenol can detect $\mathrm{CN}^{-}$with limit of detection $7 \mathrm{mM}$.
\end{abstract}

Keywords: chemosensor, colorimetric, cyanide, hydrazone, vanillin 


\section{PENDAHULUAN}

Limbah anion seperti anion sianida adalah salah satu limbah yang dihasilkan dari industri tambang emas, penyepuhan, logam dan pestisida serta dihasilkan dari proses biologis bakteri, jamur dan alga yang dapat menimbulkan permasalahan tersendiri untuk kesehatan dan lingkungan (Kang et al., 2013: Huang et al., 2012). Anion sianida memiliki sifat toksisitas sangat tinggi dengan dosis letal sebesar $0,5-3,5 \mathrm{mg} / \mathrm{Kg}$ bahkan dalam jumlah tertentu dapat menyebabkan kematian (Pati, 2016; Jayasudha et al., 2017; Cao and Wang, 2013). Anion sianida dapat mempengaruhi proses respirasi seluler karena dapat membentuk komplek sitokrom c oksidase sehingga menghambat fungsi enzim tersebut dan persediaan oksigen untuk sel (Isaad and Perwuelz, 2010; Pati, 2016). Selain $\mathrm{CN}^{-}$, anion Fluorida dengan konsentrasi tertentu dapat menyebabkan fluorosis gigi dan tulang (WHO, 2011).

Umumnya metode yang digunakan untuk menganalisis anion adalah dengan menggunakan metode kromatografi (He et al., 2019) dan elektrokimia (Lakshmi et al., 2019). Selain itu, potensiometri (Mahajan et al., 2007) dan voltametri (Safavi et al., 2004) yang termasuk metode elektrokimia juga digunakan untuk menganalisis limbah anion. Kelemahan metode tersebut adalah kurang praktis dan kurang efisien digunakan karena membutuhkan preparasi sampel dengan biaya yang cukup tinggi dan membutuhkan waktu yang lama untuk proses analisnya (Xu et al., 2012).

Metode kolorimetri merupakan suatu metode yang dikembangkan untuk mendeteksi anion dengan memanfaatkan perubahan warna antara reseptor sensor dengan anion maupun kation. Metode kolorimetri lebih praktis dan efisien digunakan jika dibandingkan dengan metode yang selama ini digunakan untuk menganalisis anion yaitu: (i) tidak membutuhkan preparasi sampel yang merupakan tahapan analisis yang cukup rumit untuk dilakukan, (2) tidak membutuhkan instrumen tertentu karena analisis anion dapat diamati langsung oleh mata (naked eye) yaitu dengan menggunakan perubahan warna yang dihasilkan dari interaksi antara reseptor dengan anion (Udhayakumari, 2018).

Beberapa kriteria dari senyawa yang dapat digunakan sebagai reseptor sensor anion adalah memiliki sisi aktif (binding site) yang berfungsi sebagai pusat interaksi antara reseptor dengan anion dan gugus kromofor yang berfungsi sebagai penghantar sinyal (signaling subunit) untuk meningkatkan intensitas perubahan warna yang dihasilkan dari interaksi antara sisi aktif dengan anion (Martinez-Manez and Sancenon, 2003). Gugus 
fungsi seperti gugus - $\mathrm{OH}$ (Reena et al, 2013), hidrazon (-NH) (Kim et al., 2012), urea (Shao, 2010) maupun ikatan rangkap $(\mathrm{C}=\mathrm{C})$ (Park et al., 2012) dapat berperan sebagai sisi aktif.

Beberapa tahun terakhir penelitian senyawa kemosensor berkembang cukup signifikan. Salah satu senyawa kemosensor sebagai sensor anion maupun kation adalah turunan hidrazon yang merupakan senyawa dengan gugus $-\mathrm{CH}=\mathrm{N}-\mathrm{NH}-$. Gugus tersebut dapat berperan sebagai sisi aktif melalui mekanisme interaksi kemodosimeter antara senyawa sensor dan anion dengan mengadisi ikatan rangkap $-\mathrm{C}=\mathrm{N}-$ maupun melalui ikatan hidrogen atau deprotonasi antara gugus -NH dan anion. Li et al., (2010) telah mensintesis senyawa azo-hidrazon yang mengandung gugus - $\mathrm{NH}$ yang berasal dari senyawa fenilhidrazon dan gugus donor yang berasal dari senyawa azo. Akan tetapi dalam pelarut DMSO ataupun campuran DMSO- $\mathrm{H}_{2} \mathrm{O}$, senyawa tersebut kurang selektif sebagai sensor anion karena menghasilkan perubahan warna yang sama yaitu dari kuning menjadi merah dengan penambahan anion fluoride, asetat dan fosfat. Selain itu, Qiao et al. (2009) juga telah mensintesis turunan senyawa hidrazon yang berasal dari fenantrolin. Dari hasil penelitian tersebut, senyawa hasil sintesis dapat digunakan sebagai senyawa sensor untuk mendeteksi anion asetat dengan perubahan warna dari kuning menjadi hijau dalam pelarut DMSO. Cao and Wang (2013) juga sudah mensintesis senyawa turunan hidrazon untuk anion fluorida dan sianida. Akan tetapi penambahan anion tersebut pada reseptor menghasilkan perubahan warna yang sama yaitu dari kuning ke hijau sehingga kurang selektif digunakan.

Berdasarkan penjelasan tersebut, pada artikel ini telah dilakukan sintesis senyawa hidrazon (E)-4-((2-(2,4-dinitrophenyl)hydrazineylidene)methyl)-2-methoxyphenol yang memiliki sisi aktif berupa gugus $-\mathrm{NH}$ dan $-\mathrm{C}=\mathrm{N}-$ yang digunakan sebagai sensor anion sianida. Selain itu, Reseptor (E)-4-((2-(2,4-dinitrophenyl)hydrazineylidene)methyl)-2methoxyphenol memiliki gugus $-\mathrm{NO}_{2}$ sebagai gugus penarik elektron yang dapat meningkatkan selektivitas dan sensitivitas reseptor terhadap anion sianida dalam pelarut asetonitril.

\section{METODE PENELITIAN}

\section{Alat dan Bahan}

Peralatan yang digunakan dalam penelitian ini adalah alat penentu titik lebur Electrotermal 9100, satu set alat refluk, satu set alat Evaporator Buchii R-124, lampu UV 
(Camac UV - Cabinet II), alat timbang elektrik (Libror EB-330 Shimadzu), spektrofotometer UV-Vis (Shimadzu UV-1800), spektrofotometer FT-IR (Shimadzu Prestige-21), kromatografi gas-spektrofotometer massa (Shimadzu QP-2010S), spektrofotometer ${ }^{1} \mathrm{H}-\mathrm{NMR}$ (JEOL JNM ECA-500, 500MHz) dan spektrofotometer ${ }^{13} \mathrm{C}$ NMR (JEOL JNM ECA-500, 125MHz).

Bahan yang digunakan dalam penelitian ini adalah vanilin $\left(\mathrm{C}_{8} \mathrm{H}_{8} \mathrm{O}_{3}\right)$, natrium hidroksida $(\mathrm{NaOH})$, asam asetat $\left(\mathrm{CH}_{3} \mathrm{COOH}\right)$ glasial, asam klorida (HCL) 37\%, etanol $\left(\mathrm{C}_{2} \mathrm{H}_{5} \mathrm{OH}\right)$, 2,4-dinitrofenilhidrazin $\left(\mathrm{C}_{6} \mathrm{H}_{6} \mathrm{~N}_{4} \mathrm{O}_{4}\right)$, DMSO, asetonitril $\left(\mathrm{CH}_{3} \mathrm{CN}\right)$, aseton $\left(\mathrm{C}_{3} \mathrm{H}_{6} \mathrm{O}\right)$, natrium fluorida $(\mathrm{NaF})$, natrium klorida $(\mathrm{NaCl})$, natrium iodida $(\mathrm{NaI})$, natrium bromida $(\mathrm{NaBr})$, natrium karbonat $\left(\mathrm{Na}_{2} \mathrm{CO}_{3}\right)$, natrium sulfat $\left(\mathrm{Na}_{2} \mathrm{SO}_{4}\right)$, natrium dihidrogen fosfat $\left(\mathrm{NaH}_{2} \mathrm{PO}_{4}\right)$, natrium asetat $\left(\mathrm{CH}_{3} \mathrm{COONa}\right)$, natrium $(\mathrm{NaCN})$. Bahan yang digunakan diproduksi oleh Merck.

\section{Sintesis Reseptor (E)-4-((2-(2,4-dinitrophenyl)hydrazineylidene $)$ methyl $)$-2-methoxy phenol}

Sebanyak $1 \mathrm{mmol}$ vanilin dilarutkan ke dalam $100 \mathrm{~mL}$ etanol. Sebanyak $1 \mathrm{mmol}$ 2,4-dinitrofenilhidrazin dan 4 tetes asam asetat glasial ditambahkan ke dalam larutan tersebut dan direfluks selama 3 jam. Hasil refluks didinginkan dan endapan yang terbentuk disaring serta dicuci dengan akuades. Padatan yang diperoleh ditentukan titik lelehnya dan dianalisis dengan FT-IR, ${ }^{1} \mathrm{H}-\mathrm{NMR}$ dan ${ }^{13} \mathrm{C}-\mathrm{NMR}$.

\section{Solvatokromik Reseptor (E)-4-((2-(2,4-dinitrophenyl)hydrazineylidene $)$ methyl)-2- methoxyphenol}

Sebanyak 3,4 x $10^{-3} \mathrm{~g}$ reseptor (E)-4-((2-(2,4-dinitrophenyl)hydrazineylidene) methyl)-2-methoxyphenol ditambahkan masing-masing $10 \mathrm{~mL}$ pelarut DMSO, aseton, asetonotril dan etanol. Perubahan warna dan panjang gelombang maksimum ditentukan dengan spektrofotometer UV-Vis.

\section{Uji Selektivitas Reseptor (E)-4-((2-(2,4-dinitrophenyl)hydrazineylidene)methyl)-2- methoxyphenol}

Sebanyak $2 \mathrm{~mL}$ larutan reseptor $(E)-4-((2-(2,4-$ dinitrophenyl)hydrazineylidene $)$ methyl)-2-methoxyphenol dengan konsentrasi $5 \times 10^{-5} \mathrm{M}$ dalam pelarut DMSO ditambahkan masing-masing $10 \mu \mathrm{L}$ larutan jenuh garam $\mathrm{NaF}, \mathrm{NaCl}, \mathrm{NaBr}, \mathrm{NaI}, \mathrm{NaCN}$, $\mathrm{Na}_{2} \mathrm{SO} 4, \mathrm{Na}_{2} \mathrm{CO}_{3}, \mathrm{CH}_{3} \mathrm{COONa}$ dan $\mathrm{NaH}_{2} \mathrm{PO}_{4}$. Spektra absorpsi ditentukan dengan spektrofotometer Ultra Violet-Visible dari panjang gelombang 200 sampai $700 \mathrm{~nm}$. Cara yang sama dilakukan untuk reseptor dalam pelarut $\mathrm{CH}_{3} \mathrm{CN}$, aseton dan etanol. 


\section{Uji Limit Deteksi Reseptor (E)-4-((2-(2,4-dinitrophenyl)hydrazineylidene)methyl)-2- methoxyphenol}

Uji titik ekuivalen dan limit deteksi anion sianda dilakukan dengan menambahkan $50 \mu \mathrm{L}$ larutan $\mathrm{NaCN}\left(1 \times 10^{-2}\right)-\left(\begin{array}{lll}10 & \mathrm{x} & 10^{-2}\end{array}\right) \mathrm{M}$ ke dalam reseptor $(E)-4-((2-(2,4-$ dinitrophenyl)hydrazineylidene)methyl)-2-methoxyphenol dengan konsentrasi $5 \times 10^{-5} \mathrm{M}$. Spektra absorpsi ditentukan dengan Ultra Violet-Visisible dari panjang gelombang 200 sampai $700 \mathrm{~nm}$.

\section{HASIL DAN PEMBAHASAN}

Sintesis dan Karakterisasi Reseptor (E)-4-((2-(2,4-dinitrophenyl)hydrazineylidene) methyl)-2-methoxyphenol

Reseptor hidrazon (E)-4-((2-(2,4-dinitrophenyl)hydrazineylidene)methyl)-2methoxyphenol disintesis dari vanilin dan 2,4-dinitrofenilhidrazin melalui reaksi adisieliminasi dengan katalis asam asetat pada suhu refluks selama 3 jam (Gambar 1). Pada sintesis tersebut diperoleh padatan merah dengan titik leleh $269,8-270,2{ }^{\circ} \mathrm{C}$ dan rendemen sebesar 79\%. Adanya gugus nitro pada reseptor 2,4-dinitrofenilhidrazin menyebabkan berkurangnya reaktivitas nukleofil $\mathrm{N}$, sehingga kemampuan nukleofil atom $\mathrm{N}$ amina primer pada reseptor 2,4-dinitrofenilhidrazin untuk mengadisi gugus karbonil pada vanilin juga semakin lemah. Selanjutnya reseptor (E)-4-((2-(2,4dinitrophenyl)hydrazineylidene)methyl)-2-methoxyphenol dikarakterisasi dengan beberapa metode spetroskopi seperti FT-IR.

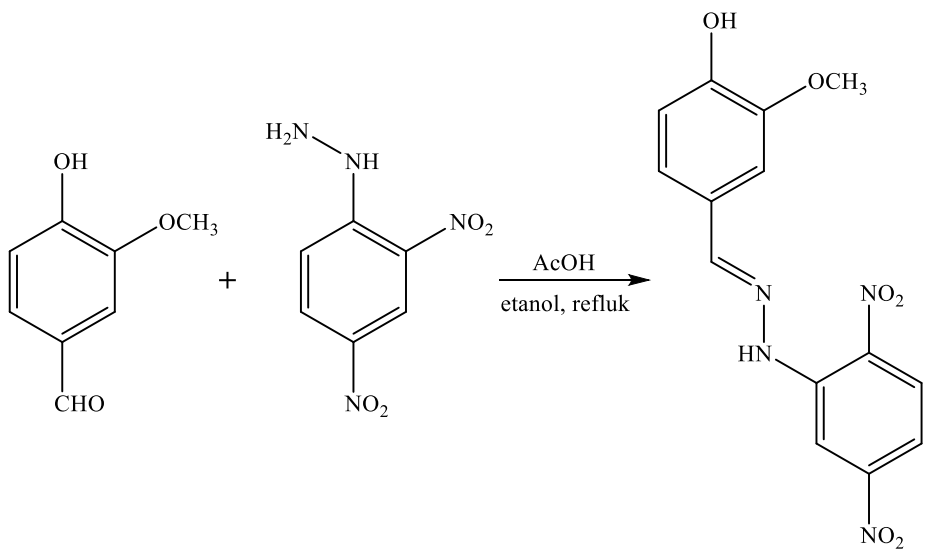

Gambar 1. Skema sintesis reseptor (E)-4-((2-(2,4-dinitrophenyl)hydrazineylidene) methyl)-2-methoxyphenol.

Spektra FT-IR reseptor (E)-4-((2-(2,4-dinitrophenyl)hydrazineylidene)methyl)-2methoxyphenol dapat dilihat pada Gambar 3. Berdasarkan spektra FT-IR $\left(\mathrm{KBr}, \mathrm{cm}^{-1}\right)$ dapat 
dilihat bahwa terjadi perubahan serapan gugus fungsi reseptor vanilin. Berdasarkan spektra FT-IR reseptor $(E)-4-((2-(2,4-d i n i t r o p h e n y l)$ hydrazineylidene) methyl)-2-methoxy phenol menunjukkan puncak baru pada bilangan gelombang $3278 \mathrm{~cm}^{-1}$ yang merupakan serapan gugus fungsi N-H dari senyawa hidrazon. Sedangkan berdasarkan spektra FT-IR Vanilin (Gambar 2) tidak terdapat serapan gugus fungsi tersebut. Selain itu, serapan baru pada bilangan gelombang $1612 \mathrm{~cm}^{-1}$ pada spektra FT-IR reseptor (Gambar 3) merupakan serapan gugus fungsi $\mathrm{C}=\mathrm{N}$ yang disertai hilangnya serapan pada bilang gelombang 1666 $\mathrm{cm}^{-1}$ (Gambar 2) yang merupakan serapan untuk gugus fungsi $\mathrm{C}=\mathrm{O}$ yang terdapat pada senyawa vanilin. Serapan lain pada bilangan gelombang 1512 dan $1334 \mathrm{~cm}^{-1}$ (Gambar 3) merupakan serapan untuk gugus fungsi $-\mathrm{NO}_{2}$.

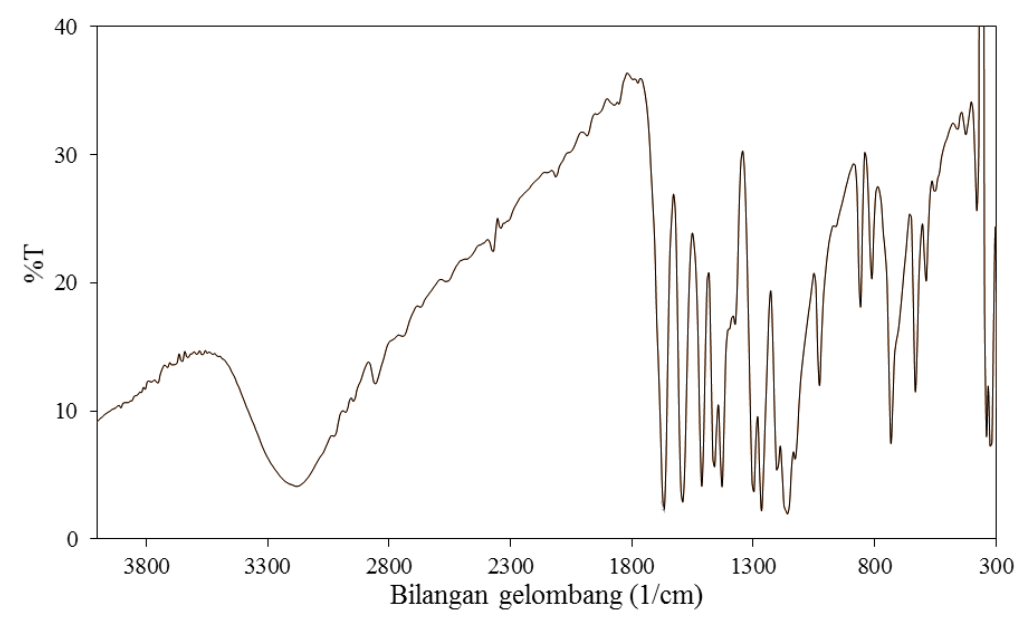

Gambar 2. Spektra FT-IR vanilin.

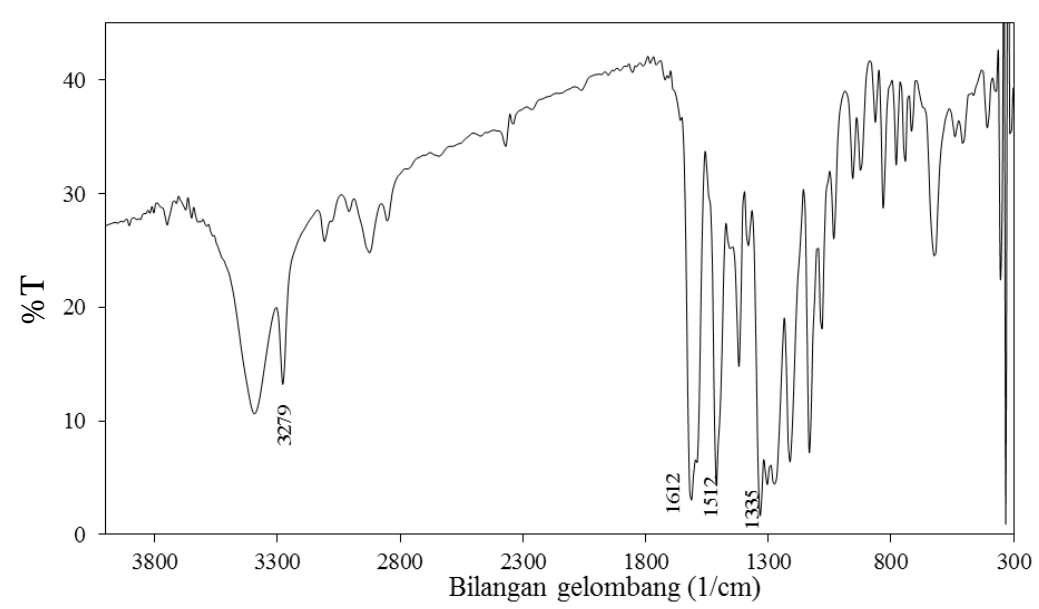

Gambar 3. Spektra FT-IR reseptor (E)-4-((2(2,4-dinitrophenyl)hydrazineylidene)methyl)2-methoxyphenol.

Senyawa hasil sintesis (E)-4-((2-(2,4-dinitrophenyl)hydrazineylidene)methyl)-2methoxyphenol kemudian dikarakterisasi dengan ${ }^{1} \mathrm{H}-\mathrm{NMR}$ (DMSO, $500 \mathrm{MHz}, \delta$ ). 
Berdasarkan spektra ${ }^{1} \mathrm{H}$ - NMR (Gambar 4) dapat dilihat bahwa terdapat 10 puncak proton. Proton A merupakan proton dari gugus hidroksi (-OH) dengan pergeseran kimia sebesar $11,58 \mathrm{ppm}(1 \mathrm{H}, s)$. Puncak proton B muncul pada $\delta 9,71 \mathrm{ppm}$ yang merupakan proton dari gugus - NH $(1 \mathrm{H}, s)$. Puncak proton $\mathrm{C}$ muncul pada $\delta 8,86 \mathrm{ppm}$ berasal dari proton aril yang diapit oleh dua gugus nitro sehingga menyebabkan pergeseran kimia ke arah downfield $(d$, $J=2,6 \mathrm{~Hz}, 1 \mathrm{H})$. Puncak D merupakan puncak dari proton $-\mathrm{CH}=\mathrm{N}$ dengan pergeseran kimia $(\delta)$ sebesar $8,58 \mathrm{ppm}(1 \mathrm{H}, s)$, sedangkan proton $\mathrm{E}$ muncul pada $\delta 8,35 \mathrm{ppm}$ merupakan proton aril yang mengalami kopling terhadap orto dan meta $(d d, J=2,6$ dan 9,7 $\mathrm{Hz}, 1 \mathrm{H})$. Puncak F muncul pada $\delta 8,09$ ppm merupakan puncak proton aril $(d, J=9,7 \mathrm{~Hz}$, $1 \mathrm{H})$ sedangkan puncak $\mathrm{G}$ muncul pada $\delta 7,39 \mathrm{ppm}$ merupakan puncak proton aril $(d, J=$ $1,3 \mathrm{~Hz}, 1 \mathrm{H})$. Puncak $\mathrm{H}$ muncul pada $\delta 7,17 \mathrm{ppm}$ merupakan puncak proton aril $(d d, J=$ $1,95$ dan $8,7 \mathrm{~Hz}, 1 \mathrm{H})$ sedangkan puncak I muncul pada $\delta 6,87$ ppm merupakan puncak proton aril $(d, J=8,5 \mathrm{~Hz}, 1 \mathrm{H})$. Puncak $\mathrm{J}$ muncul pada $\delta 3,86$ ppm merupakan puncak dari proton metil pada gugus metoksi $(s, 3 \mathrm{H})$.

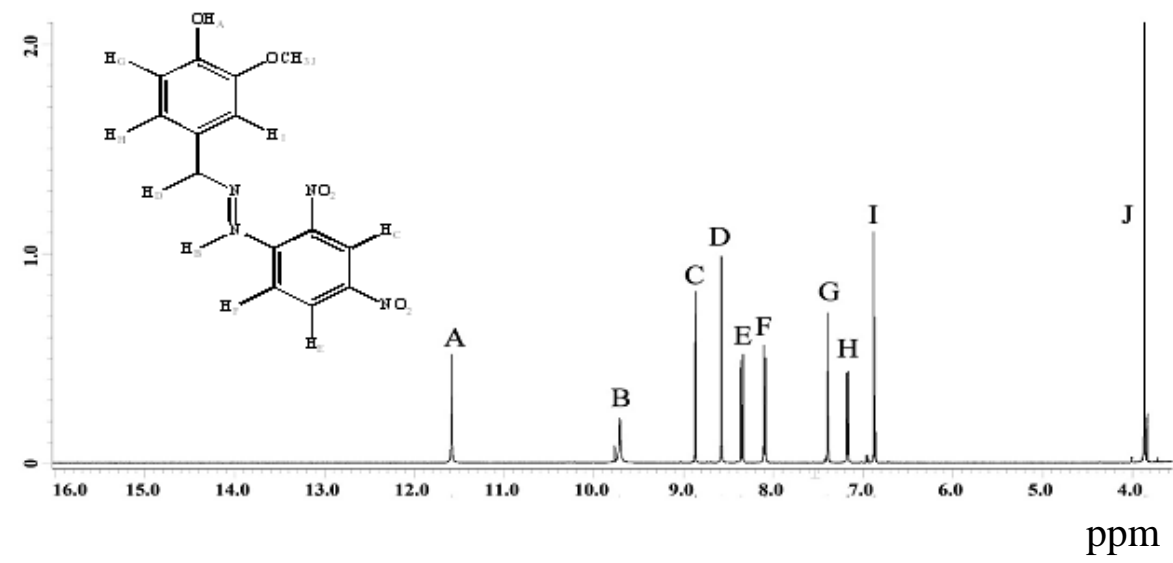

Gambar 4. Spektra ${ }^{1}$ H-NMR reseptor (E)-4-((2(2,4-dinitrophenyl)hydrazineylidene) methyl)-2-methoxyphenol.

Senyawa hasil sintesis (E)-4-((2-(2,4-dinitrophenyl)hydrazineylidene)methyl)-2methoxyphenol selanjutnya dikarakterisasi dengan ${ }^{13} \mathrm{C}-\mathrm{NMR}$ (DMSO-d6, $125 \mathrm{MHz}$ ). Berdasarkan spektra ${ }^{13} \mathrm{C}-\mathrm{NMR}$ reseptor 4-((2-(2,4-dinitrofenil)hidrazon)metil)-2metoksifenol dapat dilihat bahwa terdapat 14 puncak karbon yang berbeda (Gambar 5). Karbon A muncul pada $\delta 150,18 \mathrm{~nm}$ merupakan karbon aril dengan subtituen gugus hidroksi, sedangkan karbon B merupakan karbon aril dengan subtituen gugus metoksi muncul pada $\delta 149,64$ ppm. Karbon C berasal dari karbon aril dengan subtituen gugus amina muncul pada $\delta 148,13$ ppm. Karbon D muncul pada $\delta 144,42$ ppm merupakan 
karbon pada gugus imina (- $\mathrm{CH}=\mathrm{N}-)$. Karbon A lebih deshielding jika dibandingkan dengan karbon D karena atom oksigen lebih elektronegatif jika dibandingkan dengan atom nitrogen. Karbon $\mathrm{E}$ dan $\mathrm{H}$ berasal dari karbon aril dengan subtituen gugus nitro $\left(-\mathrm{NO}_{2}\right)$ masing-masing muncul pada $\delta 136,55$ ppm dan 125,11 ppm. Karbon F berasal dari karbon aril muncul pada $\delta 129,70$ ppm. Karbon G, I, J, K, L, dan M merupakan karbon aril masing-masing muncul pada $\delta 128,99 ; 123,11 ; 123,63 ; 116,74 ; 115,60$ dan 109,58 ppm. Karbon $\mathrm{N}$ berasal dari karbon metoksi $\left(-\mathrm{OCH}_{3}\right)$ muncul pada $\delta 55,66 \mathrm{ppm}$.

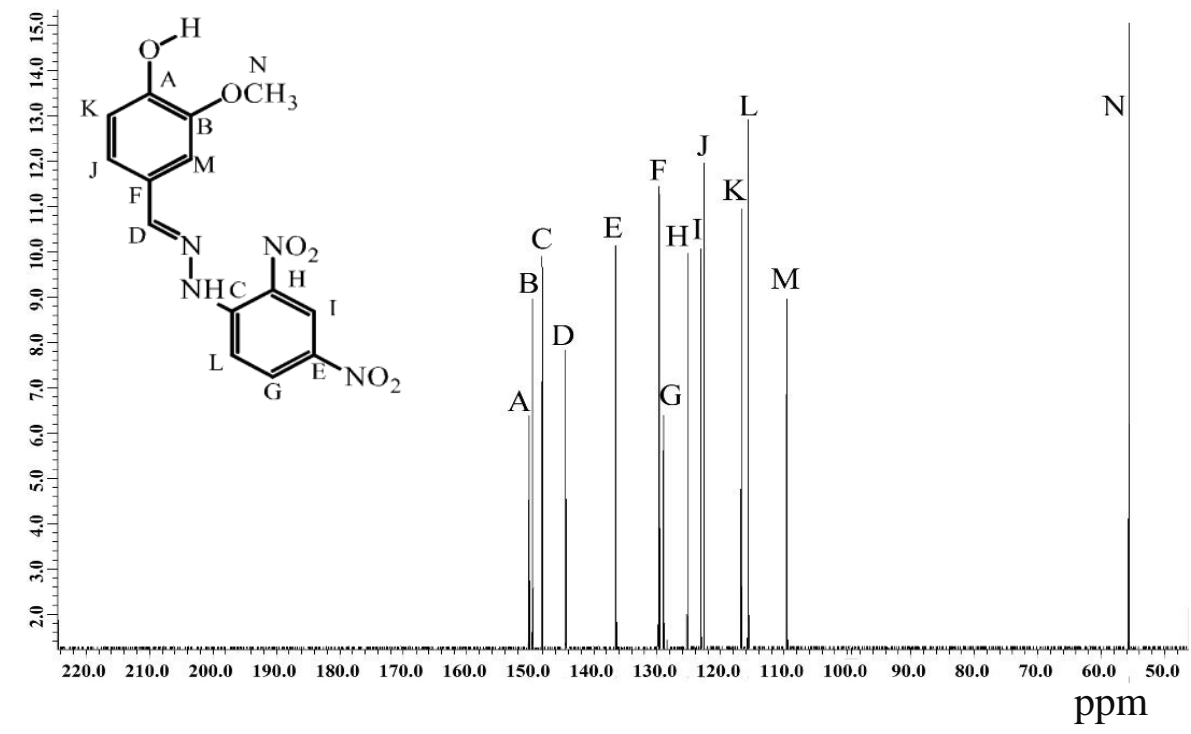

Gambar 5. Spektra ${ }^{13} \mathrm{C}-\mathrm{NMR}$ reseptor (E)-4-((2(2,4-dinitrophenyl)hydrazineylidene) methyl)-2-methoxyphenol.

\section{Uji Solvatokromik dan UV-Vis Reseptor (E)-4-((2)(2,4-dinitrophenyl) hydrazineylidene)methyl)-2-methoxyphenol}

Solvatokromik merupakan suatu uji untuk melihat perubahan warna, bentuk, intensitas, dan posisi spektra UV-Vis reseptor dalam pelarut tertentu. Selain itu digunakan untuk menentukan pelarut yang sesuai untuk uji selektivitas dan sensitivitas. Solvatokromik reseptor (E)-4-((2(2,4-dinitrophenyl)hydrazineylidene $)$ methyl $)$-2methoxyphenol dilakukan dengan melarutkan reseptor ke dalam pelarut berdasarkan kenaikan polaritas pelarut seperti DMSO, asetonitril, aseton dan etanol dengan konsentrasi masing-masing reseptor $1 \times 10^{-3} \mathrm{M}$. Berdasarkan uji solvatokromik, reseptor $(E)-4-((2(2,4-$ dinitrophenyl)hydrazineylidene)methyl)-2-methoxyphenol larut di DMSO, asetonitril dan aseton tetapi sedikit larut dalam etanol. Dalam pelarut DMSO reseptor memberikan warna orange, sedangkan pada pelarut asetonitril dan aseton memberikan warna kuning (Gambar 6). Uji solvatokhromik reseptor $(E)-4-((2(2,4$ dinitrophenyl) hydrazineylidene)methyl)-2- 
methoxyphenol kemudian dikonfirmasi dengan spektrofotometer UV-Vis untuk menentukan panjang gelombang maksimum reseptor di masing-masing pelarut. Berdasarkan spektra UV-Vis (Gambar 7) dapat dilihat bahwa reseptor (E)-4((2(2,4dinitrophenyl)hydrazineylidene) methyl)-2-methoxyphenol mempunyai panjang gelombang maksimum yang berbeda di masing-masing pelarut (Tabel 1).

Tabel 1. Panjang gelombang maksimum ( $\left.\lambda_{\text {maks }}\right) \quad(E)-4-((2(2,4$ dinitrophenyl $)$ hydrazineylidene)methyl)-2-methoxyphenol dalam pelarut DMSO, aseton dan asetonitril.

\begin{tabular}{lc}
\hline Pelarut & $\lambda_{\text {maks }}(\mathbf{n m})$ \\
\hline DMSO & 400 \\
Aseton & 397 \\
Asetonitril & 395 \\
\hline
\end{tabular}

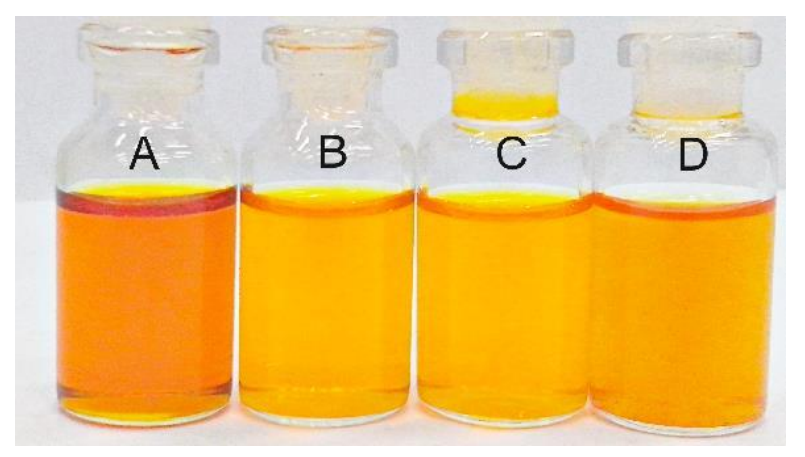

Gambar 6. Solvatokromik reseptor (E)-4-((2(2,4-dinitrophenyl)hydrazineylidene)methyl)2-methoxyphenol: (a) DMSO, (b) asetonitril, (c) aseton, (d) etanol.

Berdasarkan spektra UV-Vis solvatokromik (Gambar 7) menunjukkan bahwa terdapat perbedaan panjang gelombang maksimum reseptor $(E)-4-((2)(2,4-$ dinitrophenyl)hydrazineylidene)methyl)-2-methoxyphenol di masing-masing pelarut. Perbedaan polaritas pelarut menyebabkan pergeseran panjang gelombang ke arah batokromik dimana semakin polar suatu pelarut maka nilai pergeseran ke arah batokromik juga semakin besar. Selain itu, pergeseran panjang gelombang juga dipengaruhi oleh interaksi antara pelarut dengan reseptor. Sebagai contoh ikatan hidrogen yang dapat terbentuk antara reseptor dengan pelarut menyebabkan pergeeran panjang gelombang ke arah batokromik semakin besar (Supratman, 2010). 


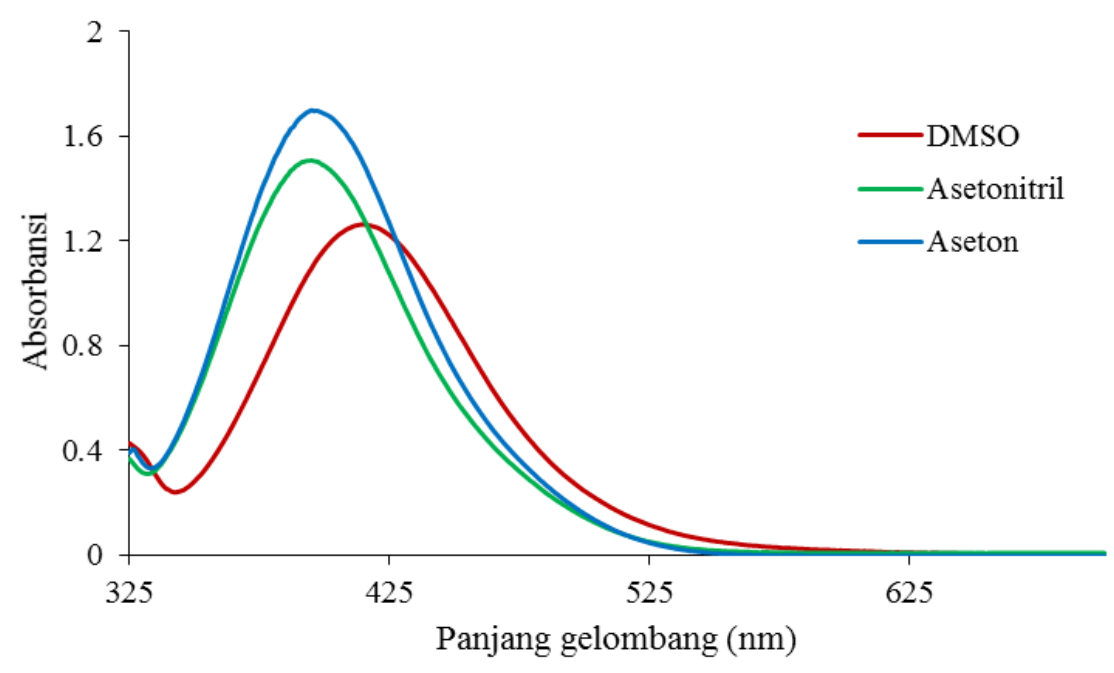

Gambar 7. Spektra UV-Vis solvatokhromik reseptor Solvatokromik reseptor $(E)-4-$ ((2(2,4-dinitrophenyl)hydrazineylidene)methyl)-2-methoxyphenol.

\section{Uji Selektivitas Reseptor (E)-4-((2(2,4-dinitrophenyl)hydrazineylidene)methyl)-2-}

\section{methoxyphenol sebagai Sensor Anion}

Uji selektivitas reseptor adalah uji yang digunakan untuk menentukan keakuratan reseptor dalam mendeteksi anion sianida terhadap anion lain berdasarkan perubahan warna yang dihasilkan. Berdasarkan uji selektivitas, reseptor (E)-4-((2) (2,4dinitrophenyl)hydrazineylidene)methyl)-2-methoxyphenol memberikan perubahan warna dari kuning ke merah terhadap anion F-, $\mathrm{CN}-, \mathrm{CO}_{3}{ }^{2-}$, dan $\mathrm{AcO}-$ dalam pelarut DMSO. Dalam pelarut asetonitril dan aseton, reseptor (E)-4-((2) $2,4-$ dinitrophenyl)hydrazineylidene)methyl)-2-methoxyphenol hanya mengalami perubahan warna terhadap anion sianida tetapi dengan perubahan warna yang berbeda. Perubahan warna dari kuning ke merah dalam pelarut asetonitril sedangkan dalam pelarut aseton mengalami perubahan warna dari kuning ke orange. Berdasarkan hasil uji selektivitas dapat disimpulkan bahwa reseptor dapat digunakan sebagai senyawa sensor sianida dalam pelarut asetonitril. Perubahan warna reseptor (E)-4-((2)(2,4-dinitrophenyl) hydrazineylidene)methyl)-2-methoxyphenol terhadap anion dalam beberapa palarut dapat dilihat pada Gambar 8. 


\section{DMSO}

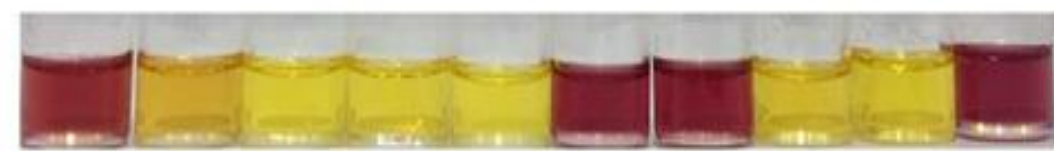

Asetonitril

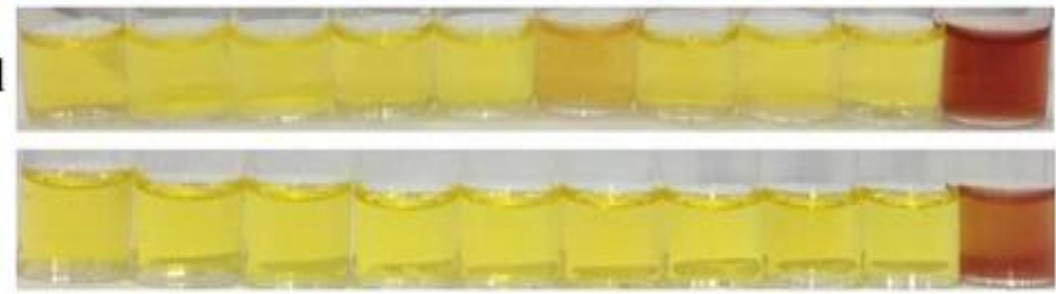

Aseton

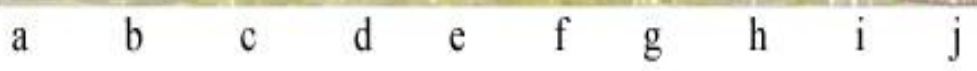

Gambar 8. Uji selektivitas reseptor terhadapa anion: (a) $\mathrm{F}^{-}$, (b) $\mathrm{Cl}^{-}$, (c) $\mathrm{Br}^{-}$, (d) $\mathrm{I}^{-}$, (e) $\mathrm{H}_{2} \mathrm{PO}_{4}^{-}$, (f) $\mathrm{CH}_{3} \mathrm{COO}^{-}$, (g) $\mathrm{SO}_{4}{ }^{2-}$ (i) reseptor, (j) $\mathrm{CN}^{-}$.

Berdasarkan spektra UV-Vis uji reseptor (E)-4-((2)(2,4dinitrophenyl)hydrazineylidene)methyl)-2-methoxyphenol sebagai sensor anion dapat dilihat bahwa dalam pelarut DMSO terjadi pergeseran batokromik dengan adanya anion $\mathrm{F}^{-}$, $\mathrm{CO}_{3}{ }^{2-}, \mathrm{CN}^{-}$dan $\mathrm{CH}_{3} \mathrm{COO}^{-}$, sedangkan dalam pelarut asetonitril dan aseton pergeseran batokromik terjadi hanya dengan anion sianida (Gambar 9). Dalam pelarut DMSO, perubahan penjang gelombang reseptor (E)-4-((2)(2,4-dinitrophenyl) hydrazineylidene)methyl)-2-methoxyphenol terjadi setelah penambahan anion $\mathrm{F}^{-}, \mathrm{CO}_{3}{ }^{2-}$ , $\mathrm{CN}^{-}$dan $\mathrm{CH}_{3} \mathrm{COO}^{-}$. Sedangkan dalam pelarut aseton dan asetonitril, perubahan panjang gelombang reseptor (E)-4-((2(2,4-dinitrophenyl) hydrazineylidene)methyl)-2methoxyphenol hanya terjadi setelah penambahan anion $\mathrm{CN}^{-}$. Hal ini membuktikan bahwa perbedaan pelarut mempengaruhi interaksi antara anion dengan reseptor. Nilai pergeseran panjang gelombang dapat dilihat pada Tabel 2 .

Tabel 2. $\lambda_{\text {maks }}(E)-4-((2(2,4-$ dinitrophenyl)hydrazineylidene $)$ methyl $)-2-m e t h o x y p h e n o l+$ anion.

\begin{tabular}{ccccc}
\hline \multirow{2}{*}{ Pelarut } & \multicolumn{5}{c}{$\lambda$ maks } \\
\cline { 2 - 5 } & $\mathbf{F}^{-}$ & $\mathbf{C N}^{-}$ & $\mathbf{C O}^{2-}$ & AcO- $^{-}$ \\
\hline DMSO & 487 & 489 & 492 & 503 \\
Asetonitril & - & 472 & - & - \\
Aseton & - & 478 & - & - \\
\hline
\end{tabular}




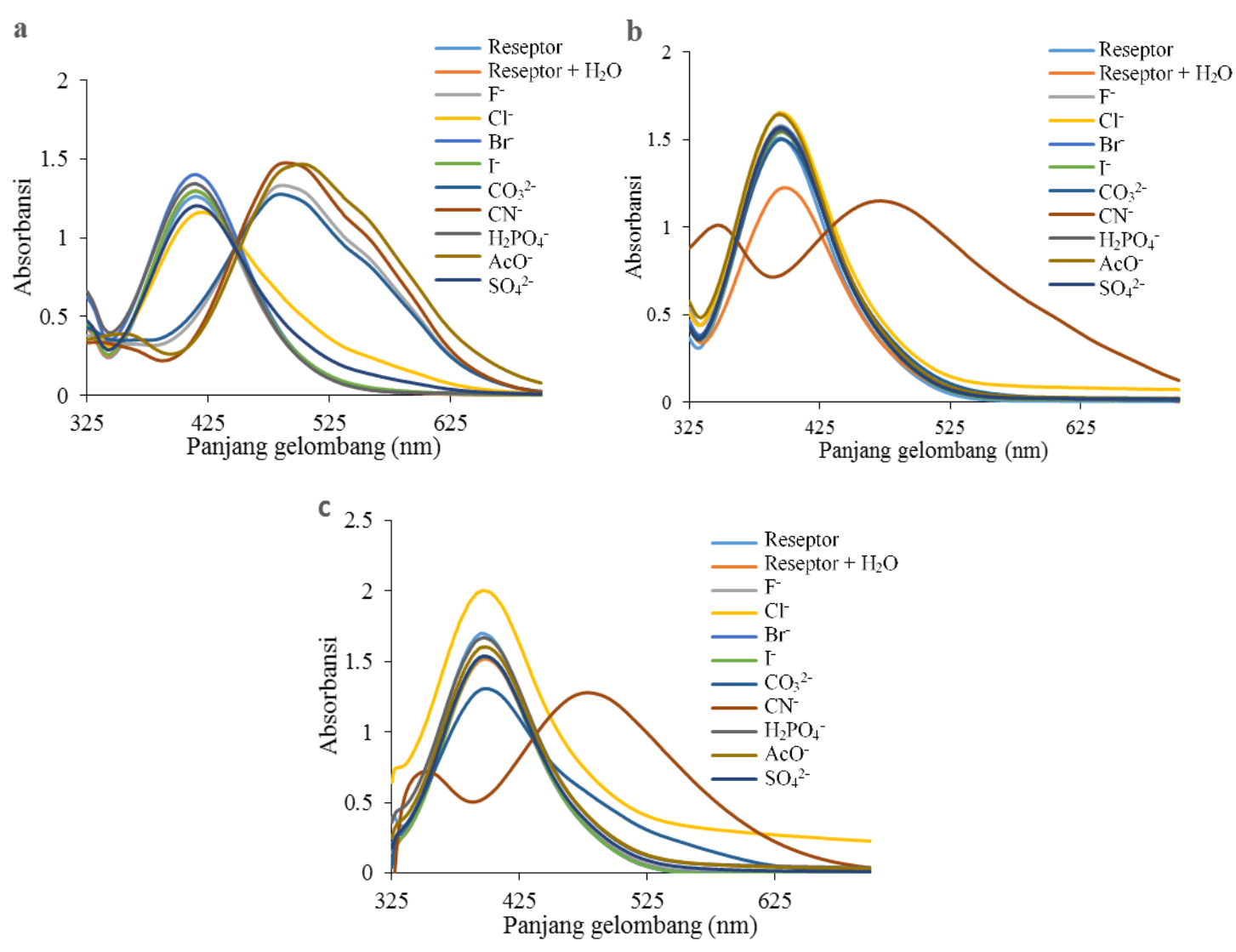

Gambar 9. Spektra UV-Vis (E)-4-((2(2,4-dinitrophenyl)hydrazineylidene)methyl)-2methoxyphenol sebagai sensor anion: (a) DMSO, (b) Asetonitril, (c) Aseton.

\section{Uji Limit Deteksi Reseptor (E)-4-((2(2,4-dinitrophenyl)hydrazineylidene)methyl)-2-} methoxyphenol

Uji titik ekuivalen dan limit deteksi reseptor (E)-4-((2)(2,4dinitrophenyl)hydrazineylidene)methyl)-2-methoxyphenol terhadap anion sianida dilakukan dengan menambahkan $50 \mu \mathrm{L}$ larutan garam $\mathrm{NaCN}(1,3,5,7,9) \times 10^{-3} \mathrm{M},(1,2,4,6,8,10) \mathrm{x}$ $10^{-2} \mathrm{M}$ dalam larutan reseptor $(E)-4-((2$ (2,4dinitrophenyl)hydrazineylidene)methyl)-2methoxyphenol $5 \times 10^{-5} \mathrm{M}$ dalam pelarut asetonitril dan kemudian dilakukan uji spektrofotometer UV-Vis yang dapat dilihat pada Gambar 10. Berdasarkan uji titik ekuivalen reseptor (E)-4-((2(2,4-dinitrophenyl)hydrazineylidene)methyl)-2-methoxyphenol terhadap anion sianida, 7-10 ekuivalen anion sianida yang ditambahkan ke dalam reseptor hanya menyebabkan warna kuning pada reseptor berubah menjadi merah, tetapi tidak terjadi perubahan panjang gelombang. Penambahan 7-10 ekuivalen anion sianida pada reseptor hanya menyebabkan penurunan absorbansi pada panjang gelombang maksimum $395 \mathrm{~nm}$. Pergeseran panjang gelombang mulai terjadi pada penambahan 20 ekuivalen anion sianida dengan ditandai munculnya puncak baru pada panjang gelombang 
maksimum 472 nm. Berdasarkan uji titik ekuivalen, reseptor (E)-4((2(2,4dinitrophenyl)hydrazineylidene)methyl)-2-methoxyphenol mampu mendeteksi anion sianida dengan konsentrasi 7 mM (Gambar 10).

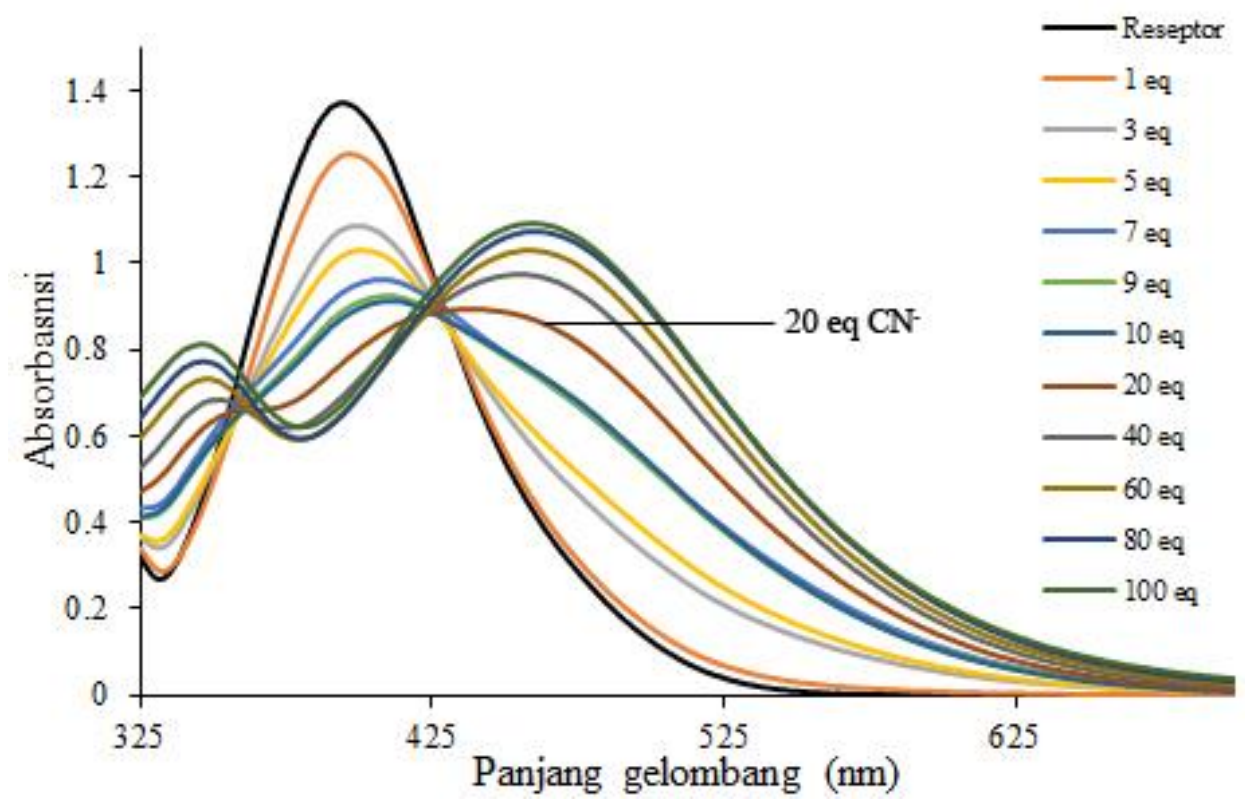

Gambar 10. Spektra UV-Vis reseptor (E)-4-((2(2,4dinitrophenyl)hydrazineylidene) methyl)-2-methoxyphenol sebagai sensor anion sianida dengan variasi konsentrasi dalam $\mathrm{mM}$.

Adanya anion sianida pada larutan reseptor (E)-4-((2) $2,4-$ dinitrophenyl)hydrazineylidene)methyl)-2-methoxyphenol menyebabkan pergeseran panjang gelombang dari $395 \mathrm{~nm}$ menjadi $472 \mathrm{~nm}(\Delta \lambda 77 \mathrm{~nm})$. Beberapa faktor yang mempengaruhi pergeseran panjang gelombang tersebut diantaranya adalah adanya gugus penarik elektron seperti gugus nitro $\left(\mathrm{NO}_{2}{ }^{-}\right)$pada reseptor. Gugus penarik elektron dapat meningkatkan polarisasi N-H dan kemampuan ikatan hidrogen reseptor tersebut (Qiao et al., 2009; Singhal et al., 2016). Selain itu, gugus nitro mampu mendelokalisasikan elektron pada gugus amina (-NH) ke arah gugus nitro yang menyebabkan kerapatan elektron pada gugus amina semakin berkurang sehingga dapat meningkatkan keasaman atom $\mathrm{H}$ dan kemampuan donor ikatan hidrogen (Singhal et al., 2016; Dalapati et al., 2014). Disisi lain gugus nitro juga dapat meningkatkan kekuatan interaksi antara reseptor dengan anion (Shang and $\mathrm{Xu}, 2009$ ). Perbedaan tingkat keasaman antara gugus hidroksi dan gugus amina pada struktur reseptor (E)-4-((2(2,4-dinitrophenyl)hydrazineylidene)methyl)-2methoxyphenol dimana proton pada gugus hidrazon menjadi lebih asam jika dibandingkan dengan proton pada gugus hidroksi menyebabkan proton pada gugus hidrazon lebih mudah berinteraksi dengan anion jika dibandingkan dengan proton pada gugus hidroksi. 
Interaksi reseptor (E)-4-((2(2,4-dinitrophenyl)hydrazineylidene $)$ methyl $)-2-$ methoxyphenol dengan anion sianida dapat dilihat pada Gambar 11. Interaksi reseptor hidrazon dengan anion sianida dapat terjadi melalui ikatan hidrogen dan deptotonasi yang terjadi pada gugus amina (Mondal et al., 2018) dan kemodosimeter yang terjadi $\mathrm{C}=\mathrm{N}$ (Pati, 2016) . Interaksi antara reseptor dengan anion sianida melalui ikatan hidrogen terjadi pada 7-10 ekuivalen yang dapat dilihat berdasarkan perubahan warna yang dihasilkan, sedangkan kemodosimeter pada gugus hidrazon terjadi pada penambahan 20 ekuivalen anion sianida dengan ditandai munculnya puncak baru pada panjang gelombang maksimum $472 \mathrm{~nm}$ (Gambar 10). Mekanisme interaksi antara reseptor dan anion dipengaruhi oleh karakter dari masing-masing anion seperti nukleofilisitas anion. Anion sianida yang merupakan nukleofil kuat membentuk ikatan hidrogen yang lemah tetapi cenderung melakukan serangan nukleofil terhadap ikatan rangkap $\mathrm{C}=\mathrm{C}$ maupun $\mathrm{C}=\mathrm{N}$ (Ferreira et al., 2019).

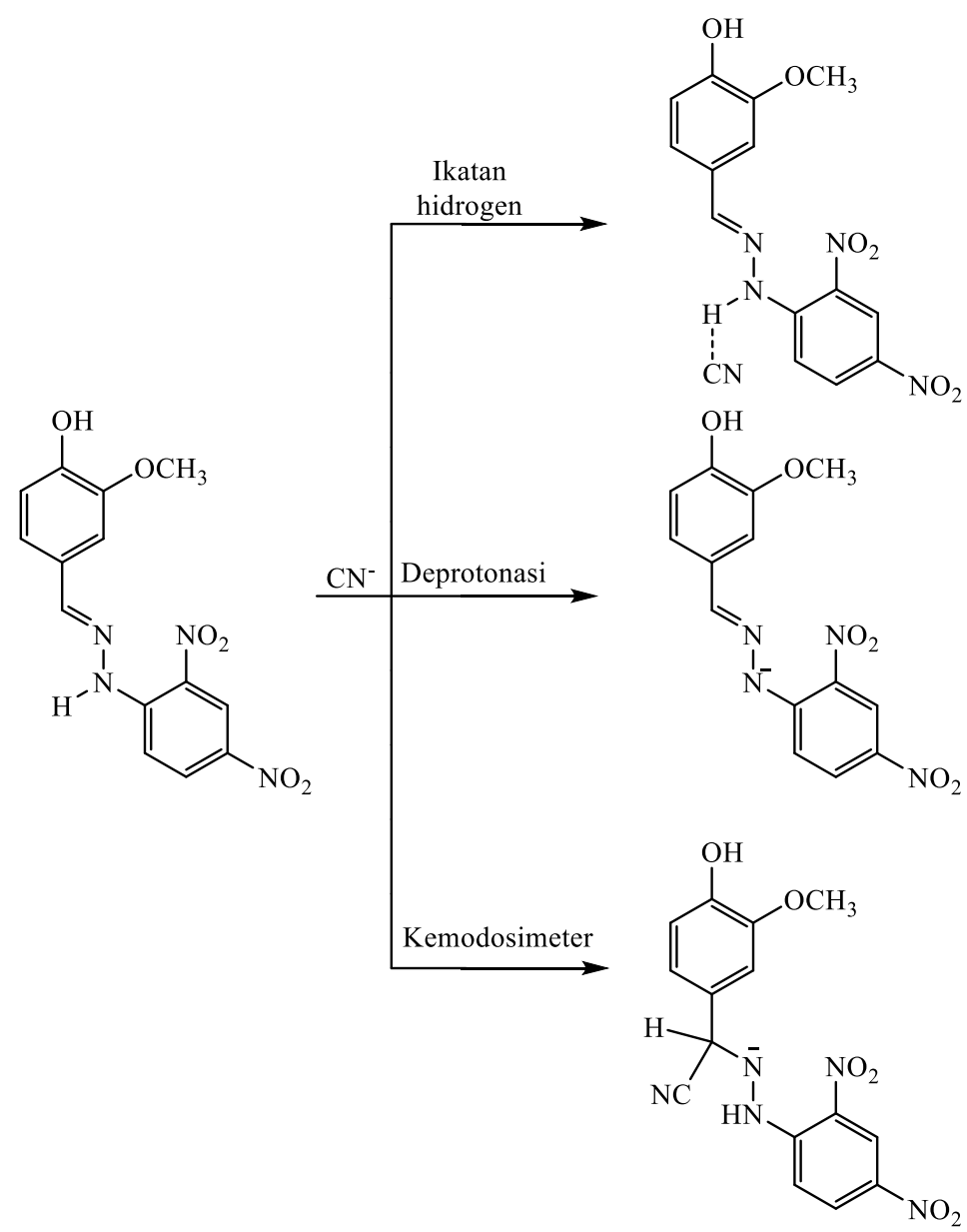

Gambar 11. Interaksi reseptor (E)-4-((2(2,4-dinitrophenyl)hydrazineylidene $)$ methyl)-2methoxyphenol dengan sianida. 


\section{KESIMPULAN}

Reseptor (E)-4-((2(2,4-dinitrophenyl)hydrazineylidene)methyl)-2-methoxyphenol dapat digunakan dengan sebagai sensor anion sianida dalam pelarut asetonitril dengan memberikan perubahan warna dari kuning ke merah dengan limit deteksi sebesar $7 \mathrm{mM}$. Adanya gugus nitro pada struktur reseptor (E)-4-((2(2,4-dinitrophenyl)hydrazineylidene $)$ methyl)-2-methoxyphenol dapat meningkatkan intesitas warna yang dihasilkan dari kompleks reseptor-anion sehingga menghasilkan pergeseran panjang gelombang ke arah batokromik dari panjang gelombang $395 \mathrm{~nm}$ menjadi $472 \mathrm{~nm}$.

\section{UCAPAN TERIMAKASIH}

Penelitian ini dibiayai oleh USU sesuai dengan kontrak Pelaksanaan Penelitian Talenta USU Tahun Anggaran 2019 Nomor: 4167/UN5.1.R/PPM/2019 tanggal 01 April 2019.

\section{DAFTAR PUSTAKA}

Cao, J., and Wang, X., 2013. An Investigation of the Deprotonation of Hydrazone-based Receptors on Interaction with Anion : Develop A Colorimetric System Distinguishing Cyanide from Anions. Tetrahedron 69(48), 10267-10271. doi: 10.1016/j.tet.2013.10.030.

Dalapati, S., Jana, S., and Guchhait, N., 2014. Anion Recognition by Simple Chromogenic and Chromo-Fluorogenic Salicylidene Schiff Base or Reduced-Schiff Base Receptors. Spectrochim. Acta, Part A: Molecular and Biomolecular Spectroscopy 129, 499-508. doi: 10.1016/j.saa.2014.03.090.

Ferreira, N. L., de Cordova, L. M., Schramm, A. D. S., Nicoleti, C. R., and Machado, V. G., 2019. Chromogenic and Fluorogenic Chemodosimeter Derived from Meldrum's Acid Detects Cyanide and Sulfide in Aqueous Medium. Journal of Molecular Liquids 282, 142-153. doi: 10.1016/j.molliq.2019.02.129.

He, X., Mei, Y., Wang, Y., Sun, W., and Shen, M., 2019. Determination of Inorganic Anions in the Whole Blood by Ion Chromatography. Journal of pharmaceutical and biomedical analysis 163, 58-63. doi: 10.1016/j.jpba.2018.09.030.

Huang, X., Gu, X., Zhang, G., and Zhang, D., 2012. A Highly Selective Fluorescence Turn-on Detection of Cyanide Based on the Aggregation of Tetraphenylethylene Molecules Induced by Chemical Reaction. Chemical Communications 48(100), 12195-12197. doi: 10.1039/c2cc37094h.

Isaad, J., and Perwuelz, A., 2010. New Color Chemosensors for Cyanide Based on Water Soluble Azo Dyes. Tetrahedron Lett., 51(44), 5810-5814. doi: 10.1016/j.tetlet.2010.08.098.

Jayasudha, P., Manivannan, R., and Elango, K. P. 2017. Benzoquinone Based Chemodosimeters for Selective and Sensitive Colorimetric and Turn-on Fluorescent 
Sensing of Cyanide in Water. Sens. Actuators, B: Chemical, 251(2), 380-388. doi: 10.1016/j.snb.2017.05.105.

Kang, J., Song, E. J., Kim, H., Kim, Y. H., Kim, Y., Kim, S. J., and Kim, C., 2013. Specific Naked Eye Sensing of Cyanide by Chromogenic Host: Studies on The Effect of Solvents. Tetrahedron Letters 54(8), 1015-1019. doi: 10.1016/j.tetlet.2012.12.053.

Kim, Y. H., Choi, M. G., Im, H. G., Ahn, S., Shim, I. W., and Chang, S. K., 2012. Chromogenic Signalling of Water Content in Organic Solvents by Hydrazone-Acetate Complexes. Dyes Pigments 92(3), 1199-1203. doi: 10.1016/j.dyepig.2011.07.019.

Lakshmi, P. R., Jayasudha, P., and Elango, K. P., 2019. Selective Chromogenic Detection of Cyanide in Aqueous Solution - Spectral, Electrochemical and Theoretical Studies. Spectrochimia Acta, Part A: Molecular and Biomolecular Spectroscopy 213, 318323. doi: 10.1016/j.saa.2019.01.074.

Li, Y., Li, J., Lin, H., Shao, J., Cai, Z.-S., and Lin, H., 2010. A Novel Colorimetric Receptor Responding AcO- Anions Based on an Azo Derivative in DMSO and DMSO/Water Solution. Journal of Luminescence 130(3), 466-472. doi: 10.1016/j.jlumin.2009.10.015.

Mahajan, R. K., Kaur, R., Miyake, H., and Tsukube, H., 2007. Zn(II) Complex-based Potentiometric Sensors for Selective Determination of Nitrate Anion. Analytical Chimia Acta 584(1), 89-94. doi: 10.1016/j.aca.2006.11.011.

Martinez-Manez, R., and Sancenon, F., 2003. Fluorogenic and Chromogenic Chemosensors and Reagents for Anions. Chemical Reviews 103, 4419-4476.

Mondal, J., Manna, A. K., and Patra, G. K., 2018. Highly Selective Hydrazone Based Reversible Colorimetric Chemosensors for Expeditious Detection of $\mathrm{CN}-$ in Aqueous Media. Inorganica Chimica Acta, 474, 22-29. doi: 10.1016/j.ica.2018.01.013.

Park, S., Hong, K. H., Hong, J. I., and Kim, H. J., 2012. Azo Dye-based Latent Colorimetric Chemodosimeter for the Selective Detection of Cyanides in Aqueous Buffer. Sensors and Actuators, B: Chemical 174, 140-144. doi: 10.1016/j.snb.2012.08.038.

Pati, P. B., 2016. Organic Chemodosimeter for Cyanide: A Nucleophilic Approach. Sensors and Actuators, B: Chemical 222, 374-390. doi: 10.1016/j.snb.2015.08.044.

Qiao, Y.-H., Lin, H., Shao, J., and Lin, H.-K., 2009. A Highly Selective Naked-Eye Colorimetric Sensor for Acetate Ion Based on 1,10-phenanthroline-2,9dicarboxyaldehyde-di-(p-substitutedphenyl-hydrazone). Spectrochimia Acta, Part A: Molecular and Biomolecular Spectroscopy 72(2), 378-381. doi: 10.1016/j.saa.2008.10.007.

Reena, V., Suganya, S., and Velmathi, S., 2013. Synthesis and Anion Binding Studies of Azo-Schiff Bases: Selective Colorimetric Fluoride and Acetate Ion Sensors. Journal $f$ Fluorine Chemistry 153, 89-95. doi: 10.1016/j.jfluchem.2013.05.010.

Safavi, A., Maleki, N., and Shahbaazi, H. R., 2004. Indirect Determination of Cyanide Ion and Hydrogen Cyanide by Adsorptive Stripping Voltammetry at A Mercury Electrode. Analytical Chimia Acta 503(2), 213-221. doi: 10.1016/j.aca.2003.10.032.

Shang, X., and Xu, X., 2009. The Anion Recognition Properties of Hydrazone Derivatives Containing Anthracene. BioSystems 96(2), 165-171. doi: 10.1016/j.biosystems.2009.01.003. 
Shao, J., 2010. A Novel Colorimetric and Fluorescence Anion Sensor with A Urea Group as Binding Site and A Coumarin Group as Signal Unit. Dyes and Pigments 87(3), 272-276. doi: 10.1016/j.dyepig.2010.04.007.

Singhal, D., Gupta, N., and Singh, A. K., 2016. The Anion Recognition Properties of A Novel Hydrazone Based on Colorimetric and Potentiometric Studies. Mater. Sci. Eng. C 58, 548-557. doi: 10.1016/j.msec.2015.08.068.

Supratman, U. 2010. Elusidasi Struktur Senyawa Organik. Widya Padjadjaran. Bandung

Udhayakumari, D., 2018. Chemical Chromogenic and Fluorogenic Chemosensors for Lethal Cyanide Ion. A Comprehensive Review of the Year 2016. Sensors and Actuators B: Chemical 259, 1022-1057. doi: 10.1016/j.snb.2017.12.006.

WHO., 2011. Guidelines for Drinking-water Quality (fourth). WHO Press, Geneva.

Xu, J. F., Chen, H. H., Chen, Y. Z., Li, Z. J., Wu, L. Z., Tung, C. H., and Yang, Q. Z., 2012. A Colorimetric and Fluorometric Dual-Modal Chemosensor for Cyanide in Water. Sensors and Actuators, B: Chemical 168, 14-19. doi: 10.1016/j.snb.2011.12.101. 